\title{
Rancang Bangun Alat Ukur Konsentrasi Oksigen yang Dihasilkan oleh Fotobioreaktor Mikroalga Chlorella vulgaris Menggunakan Sensor SK-25F
}

\author{
Aminah Nurrrahmawati, Harmadi \\ Laboratorium Elektronika dan Instrumentasi, Jurusan Fisika FMIPA Universitas Andalas \\ Kampus Unand, Limau Manis, Padang, 25163 \\ e-mail : aminahnurrahma@yahoo.co.id
}

\begin{abstract}
ABSTRAK
Telah dilakukan perancangan alat ukur konsentrasi oksigen yang dihasilkan oleh fotobioreaktor mikroalga Chlorella vulgaris. Rancangan alat menggunakan sensor SK-25F dengan penguat noninverting sebagai pengondisi sinyal, mikrokontroler Atmega328 sebagai pengolah data serta LCD sebagai piranti penampil. Besar sensitifitas alat adalah 0,478 dan $\mathrm{R}^{2}=0,980$. Persen error rata-rata yang didapatkan sebesar 1,383\% dibandingkan dengan alat ukur acuan Gas Alert Microclip. Pengukuran dilakukan pada fotobioreaktor yang disuplai dan tidak disuplai karbondioksida. Fotobioreaktor menggunakan tiga jenis sumber cahaya yaitu lampu halogen, LED dan cahaya matahari serta pada kondisi tanpa cahaya (0 lux). Konsentrasi oksigen maksimum dihasilkan oleh fotobioreaktor yang disinari lampu halogen dengan intensitas cahaya 5000 lux dengan suplai karbondioksida sebesar 20,96\%. Konsentrasi maksimum juga dihasilkan oleh fotobioreaktor yang disinari cahaya matahari dengan diberi suplai karbondioksida pada jam 15.00 WIB.

Kata kunci: fotobioreaktor, mikroalga Chlorella vulgaris, sensor SK-25F, konsentrasi oksigen.
\end{abstract}

\section{ABSTRACT}

Oxygen concentration measuring device for Chlorella vulgaris microalgae photobioreactor using SK$25 F$ sensor has been designed. The design of device used SK-25F sensor with non-inverting amplifier as signal amplifier, Atmega328 microcontroller as data processor, and LCD as display device. The sensitivity value of the device was 0.478 and $\mathrm{R}^{2}=0.980$. The average error of the device was $1.383 \%$ to the reference device Gas Alert Microclip..The measurement was done on two photobioreactors, first on photobioreactor without carbon dioxide supply and second onphotobioreactor with carbon dioxidesupply. The photobioreactors were illuminated with halogen lamp, blue LED, solar light and no light (0 lux). The maximum concentration of oxygen was obtained by photobioreactor using 5000 lux halogen lampwith a supply of carbon dioxide, it was 20.96\%. The maximum concentration was also obtained by photobioreactor using solar light with dioxide carbon supply at $03.00 \mathrm{pm}$.

Keywords:Photobioreactor, Chlorella vulgaris microalgae, SK-25F oxygen sensor, oxygen concentration.

\section{PENDAHULUAN}

Global warming (pemanasan global) semakin hari semakin meningkat seiring dengan munculnya pabrik-pabrik industri di dunia yang menghasilkan limbah dalam bentuk gas rumah kaca termasuk di dalamnya adalah emisi gas karbon dioksida. Banyak penanganan yang telah dilakukan untuk mengurangi pemanasan global seperti pembuatan bioreaktor dengan menggunakan mikroalga (Bishop dan Davis, 2000).

Mikroalga merupakan organisme berkloroplas yang menghasilkan oksigen melalui proses fotosintesis. Jumlahnya yang melimpah dan cara perkembangbiakan yang mudah, memungkinkan untuk menjadikan mikroalga sebagai sumber daya terbarukan. Mikroalga dinilai efektif mereduksi emisi karbon dioksida melalui proses fotosintesis (Santoso, 2011). Keuntungan penggunaan mikroalga dalam proses mitigasi emisi gas karbon dioksida adalah prosesnya berjalan alami dan sangat ramah lingkungan, mudah dikembangbiakan serta memiliki potensi untuk mengurangi gas rumah kaca (Chrismadha dkk., 2000).

Fotobioreaktor merupakan bioreaktor yang digabungkan dengan sumber cahaya tertentu sebagai asupan energi cahaya kedalam reaktor (Santoso, 2011). Mikroalga dapat digunakan sebagai reaktor pada fotobioreaktor dan fotosintesis merupakan reaksi yang terjadi di dalamnya. Secara teknis, fotobioreaktor menggunakan emisikarbon diokssida yang diinjeksikan ke fotobioreaktor berisi mikroalga dengan media air $\left(\mathrm{H}_{2} \mathrm{O}\right)$. Mikroalga mengikat karbon dioksida dan menghasilkan oksigen dengan bantuan sinar matahari (lampu). Alat ukur konsentrasi 
oksigen dperlukan untuk mengetahui berapa konsentrasi oksigen yang dihasilkan oleh suatu fotobioreaktor.Alat ukur konsentrasi oksigen yang ada dipasaran dinilai kurang efektif dalam mengukur konsentrasi oksigen yang memiliki range pengukuran yang kecil. Ersan (2013) telah merancang alat ukur konsentrasi oksigen dengan menggunakan sensor oksigen KE-50 dengan penampil menggunakan PC, namun alat tersebut lebih dikhususkan untuk mengukur konsentrasi oksigen yang dihasilkan oleh motor bensin, sehingga alat tersebut kurang efektif untuk mengukur konsentrasi oksigen yang dihasilkan oleh fotobioreaktor.

Rancang bangun alat ukur konsentrasi oksigen yang digunakan untuk mengukur konsentrasi oksigen yang dihasilkan oleh fotobioreaktor telah dirancang oleh Daniyati dkk. (2012) dengan menggunakan sensor oksigen KE-50 dengan penampil menggunakan PC. Kelemahan dari alat yang dirancang oleh Daniyati dkk. (2012) adalahpenampil yang masih menggunakan PC, sehingga sistem menjadi tidak portable dan rumit dalam penggunaannya..

Masih kurangnya penelitian tentang rancang bangun alat ukur oksigen untuk mengukur konsentrasi oksigen yang dihasilkan oleh fotobioreaktor, mendorong penulis untuk melakukan penelitian dengan judul Rancang Bangun Alat Ukur Konsentrasi Oksigen yang Dihasilkan oleh Fotobioreaktor Mikroalga Chlorella vulgaris dengan Menggunakan Sensor SK-25F. Penulis memilih sensor SK-25F dikarenakan sensor tersebut memiliki linearitas yang baik, sinyal keluaran yang stabil dan tidak memerlukan catu daya dalam pennggunannya (Figaro, 2012).

\section{METODE}

Alat ukur konsentrasi oksigen yang dihasilkan oleh fotobioreaktor Chlorella vulgarismenggunakan sensor SK-25F terdiri atas 2 bagian utama, yaitu perancangan perangkat keras (hardware) dan perancangan perangkat lunak (software). Penelitian ini dilakukan dengan tahapan kerja yaitu studi literatur, perancangan perangkat keras dan perangkat lunak, karakterisasi sensor SK-25F, perancangan LCD, perancangan rangkaian secara keseluruhan, pengujian akhir alat dan pengumpulan, dan analisis data. Perancangan perangkat keras terdiri dari perancangan sistem sensor (sensor SK-25F dan penguat non-inverting) dengan Arduino Uno. Perancangan perangkat lunak (software) menggunakan Arduino Uno IDE. Diagram blok sistem alat ukur konsentrasi oksigen dapat dilihat pada Gambar 1.

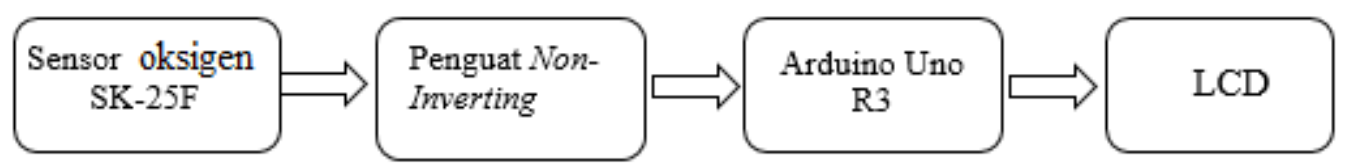

Gambar 1 Diagram blok sistem alat ukur konsentrasi oksigen

Prinsip kerja alat ukur diawali dengan sensor oksigen SK-25F mendeteksi konsentrasi gas oksigen yang dihasilkan oleh fotobioreaktor. Keluaran dari sistem sensor adalah tegangan analogyang kemudian diolah dengan ADC pada Arduino Uno. Tegangan analog tersebut diubah ke tegangan digital. Selanjutnya Arduino memproses data untuk menampilkan hasil keluaran sensor ke LCD 2x16 karakter. Skema bentuk fisik alat ukur konsnetrasi oksigen dapat dilihat pada Gambar 2.

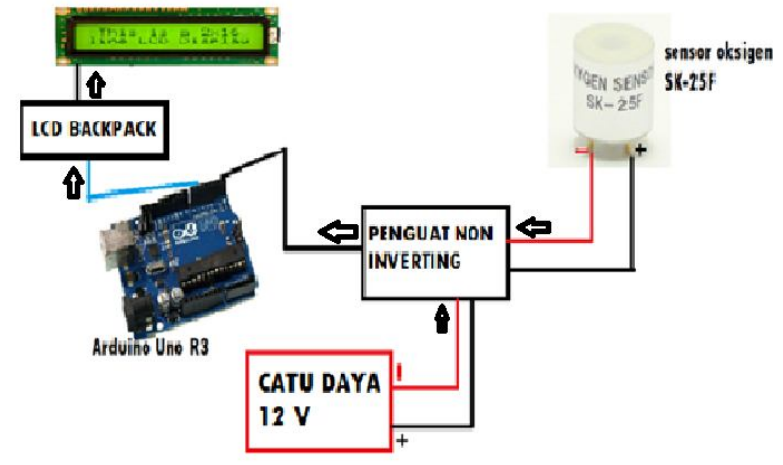

Gambar 2 Rancangan skema bentuk fisik alat 
Fotobioreaktor terdiri dari dua buah tabung yang berisi mikroalga Chlorella vulgaris dimana salah satu tabung mikroalga diberi suplai $\mathrm{CO}_{2}$ dari tabung $\mathrm{CO}_{2}$ dan tabung mikroalga lainnya tidak diberi suplai $\mathrm{CO}_{2}$. Sumber Cahaya yang digunakan pada fotobioreaktor adalah LED, lampu halogen dan cahaya matahari. Pengukuran dilakukan dengan cara meletakkan sensor diatas fotobioreaktor yang telah dilapisi aluminium foil, lalu oksigen yang dihasilkan oleh fotobioreaktor dideteksi oleh sensor oksigen. Skema rancangan alat ukur konsentrasi oksigen yang telah dihubungkan dengan fotobioreaktor dapat dilihat pada Gambar 3.

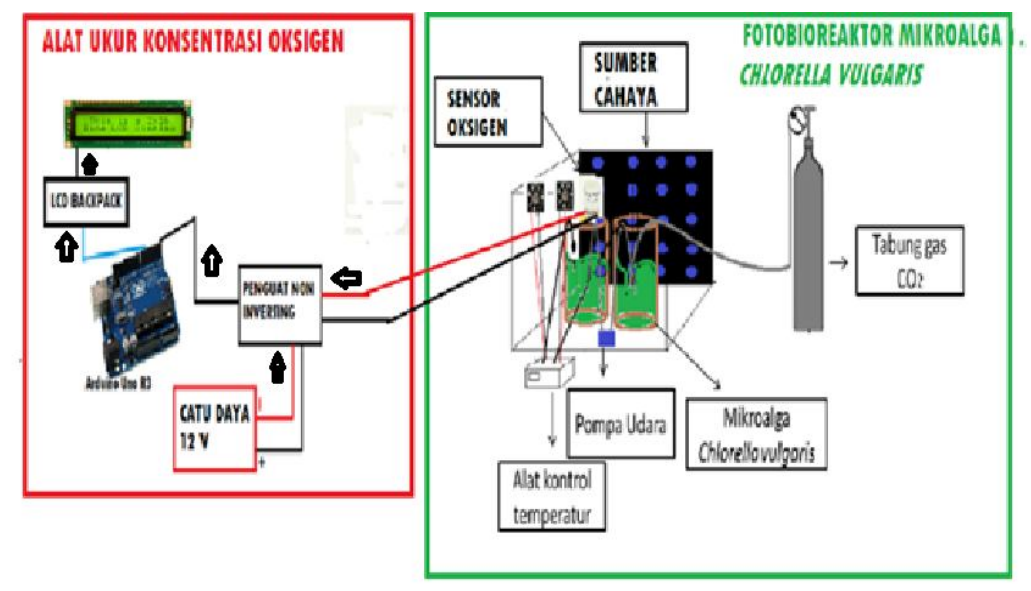

Gambar 3 Rancangan alat ukur konsentrasi oksigen yang dihubungkan dengan fotobioreaktor

\subsection{Pengkarakterisasian Sensor Oksigen SK-25F}

Karakterisasi sensor oksigen dilakukan dengan menvariasikan konsentrasi gas oksigen yang dialirkanke sensor. Nilai konsentrasi oksigen yang dialirkan ke sensor diukur menggunakan 2 alat ukur konsentrasi oksigen yang berbeda. Hal ini bertujuan untuk melihat respon sensor apabila dibandingkan dengan dua alat ukur konsentrasi oksigen yang berbeda. Alat yang yang pertama Biogas 5000 Analyzer dan alat yang kedua adalah Gas Alert Microclip. Nilai konsentrasi oksigen yang terukur oleh kedua alat ukur dibandingkan dengan tegangan keluaran yang dihasilkan oleh sensor oksigen SK-25F. Skema proses pengkarakterisasian sensor oksigen SK-25F dapat dilihat pada Gambar 4 dan Gambar 5.
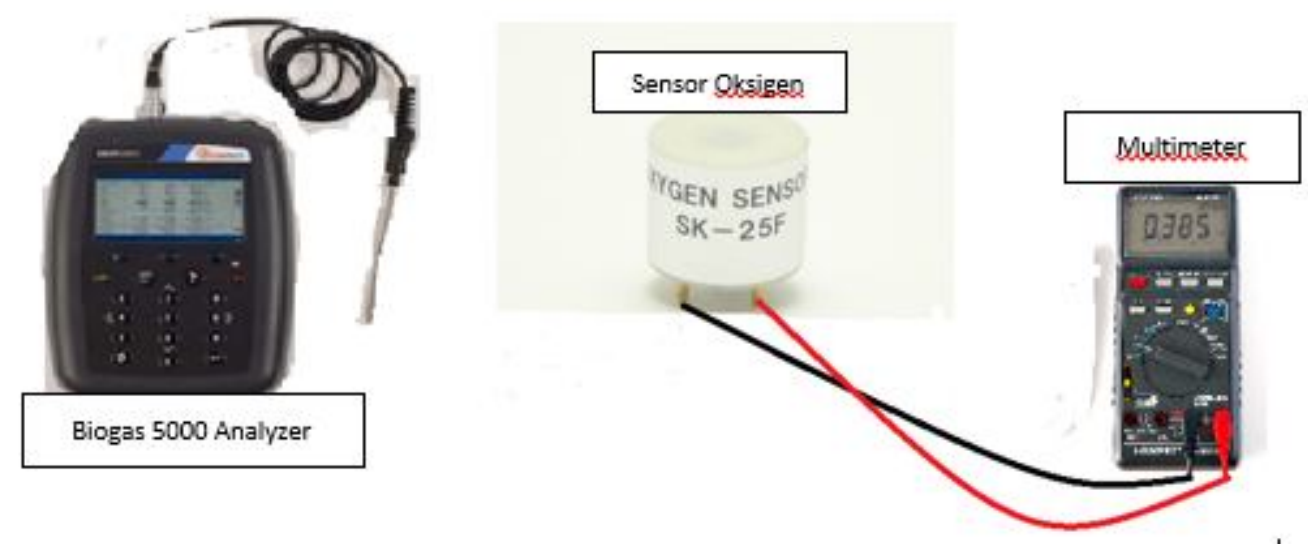

Gambar 4 Skematik pengarakterisasian sensor dengan menggunakan Biogas 5000 Analyzer.

Gambar 4 menunjukkan skematik pengkarakterisasian sensor dengan menggunakan Biogas 5000 Analyzer. Alat ukur dan sensor hanya diujikan pada udara bebas, lalu dilihat perubahan kosentrasi oksigen yang terukur pada alat ukur. Lima variasi konsentrasi oksigen yang terukur pada alat ukur dibandingkan dengan tegangan keluaran sensor untuk setiap nilai konsentrasi oksigen. Skema pengkarakterisasian sensor dengan menggunakan alat ukur konsentrasi oksigen Gas Alert Microclipdapat dilihat pada Gambar 5. 


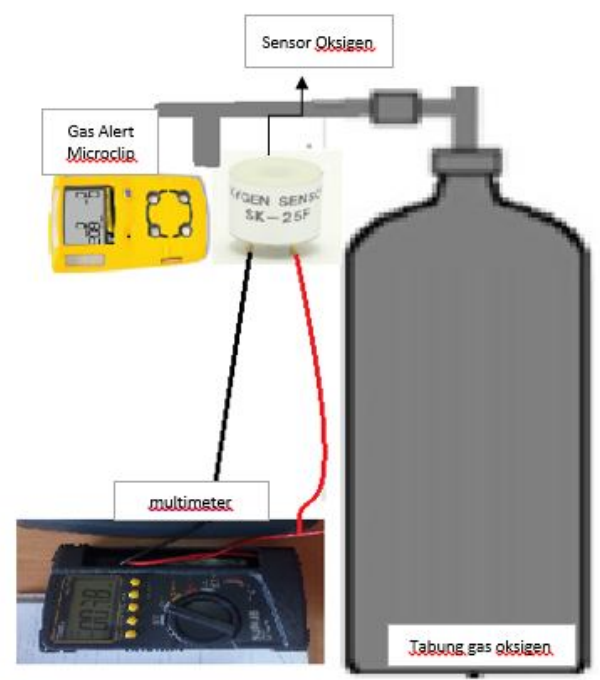

Gambar 5 Skematik karakterisasi sensor dengan menggunakan Gas Alert Microclip

Gambar 5 menunjukkan skematik pengkarakterisasian sensor dengan cara sensor dan alat ukur diposisikan tepat di dekat cerobong tabung gas oksigen. Tegangan keluaran sensor dibandingkan dengan nilai konsentrasi yang terukur pada alat ukur konsentrasi oksigen. Lima variasi nilai konsentrasi oksigen diambil lalu dicatat tegangan keluaran dari sensor untuk setiap nilai konsentrasi oksigen yang diberikan.

\subsection{Perancangan Rangkaian Pengondisi Sinyal}

Sensor oksigen SK-25F memiliki tegangan keluaran yang masih dalam skala mV. Skala keluaran sensor yang masih dalam skala $\mathrm{mV}$ menyebabkan keluaran sensor tidak dapat terbaca oleh mikrokontroler, sehingga dibutuhkan suatu elemen pengondisi sinyal berupa penguat noninverting. Penguat non-inverting dipilih untuk menguatkan tegangan keluaran sensor menjadi 0$5 \mathrm{~V}$ agar dapat dibaca oleh mikrokontroler. Skematik rangkaian penguat non-inverting dapat dilihat pada Gambar 6.

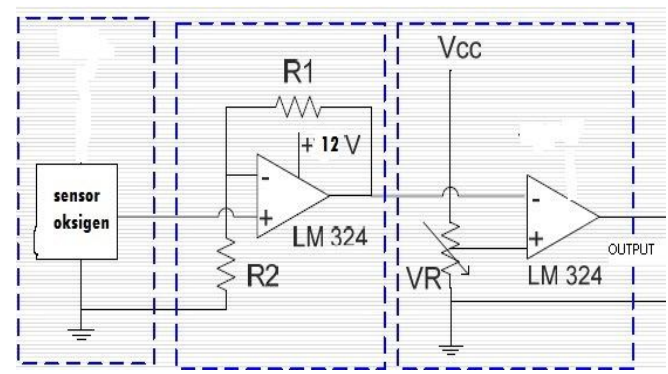

Gambar 6 Skematik rangkaian penguat non-inverting

Gambar 6 menunjukkan skema rangkaian penguat non-inverting. Cara kerja dari rangkaian tersebut adalah keluaran dari sensor dihubungkan langsung ke masukan non-inverting op-amp. Masukan dimulai dari kaki (+) sensor SK-25F masuk ke kaki (+) op-amp lalu dihubungkan ke port A2 Arduino Uno. IC yang digunakan adalah LM324N dengan R1 $=1 \mathrm{k} \Omega$, $\mathrm{R} 2=200 \mathrm{k} \Omega, \mathrm{R} 3=10 \mathrm{k} \Omega$ dan $\mathrm{R} 4=20 \mathrm{k} \Omega$. Tegangan untuk suplai adalah catu daya $12 \mathrm{~V}$.

\subsection{Perancangan Perangkat Lunak Sistem}

Perancangan diagram alir perangkat lunak pada mikrokontroler Arduino Uno untuk penelitian ini dapat dilihat pada Gambar 7. Apabila sistem dihidupkan maka arduino melakukan inisialisasi data diport input Arduino Uno yaitu tegangan keluaran dari sensor yang telah dikuatkan dengan rangkaian penguat non-inverting. Nilai tegangan keluaran sistem sensor yang mewakili nilai konsentrasi oksigen diproses pada ADC, lalu nilai konsentrasi oksigen akan ditampilkan pada LCD. 


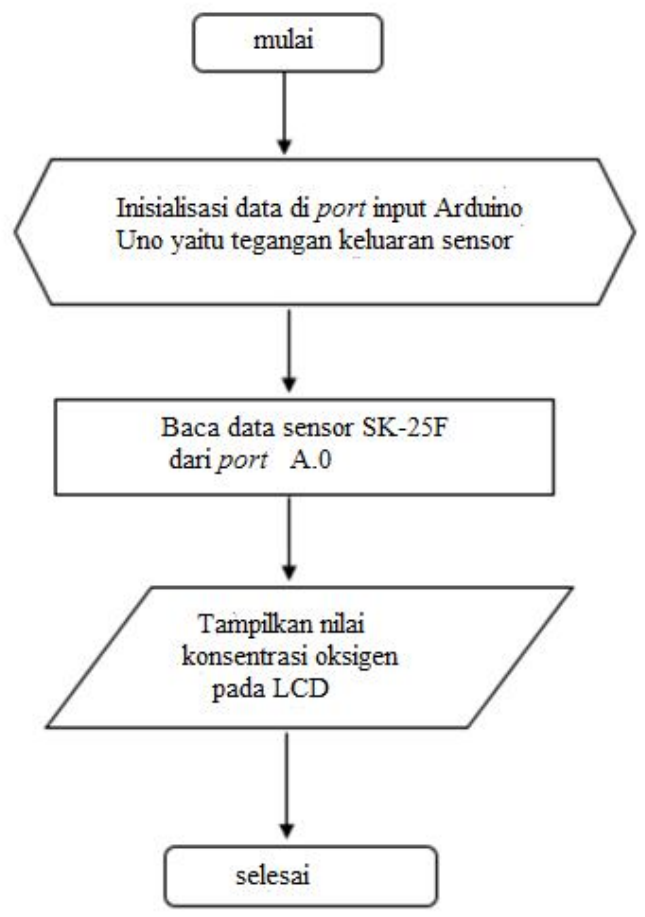

Gambar 7 Diagram alir perangkat lunak sistem

\section{HASIL DAN DISKUSI}

Hasil rancang bangun alat ukur oksigen yang diemisi oleh fotobioreaktor menggunakan sensor SK-25F telah dilakukan dengan beberapa pengujian.Pengujian meliputi pengujian perangkat keras (hardware) dan perangkat lunak (software).

Hasil rancangan fotobioreaktor dan alat ukur konsentrasi oksigen terintegrasi dalam satu instalasi. Fotobioreaktor yang terdiri dari sumber cahaya, tabung gas $\mathrm{CO}_{2}$, dan kontrol temperatur dioperasikan bersamaan dengan alat ukur konsentrasi oksigen. Hasil rancangagn perangkat keras keseluruhan dapat dilihat pada Gambar 8.

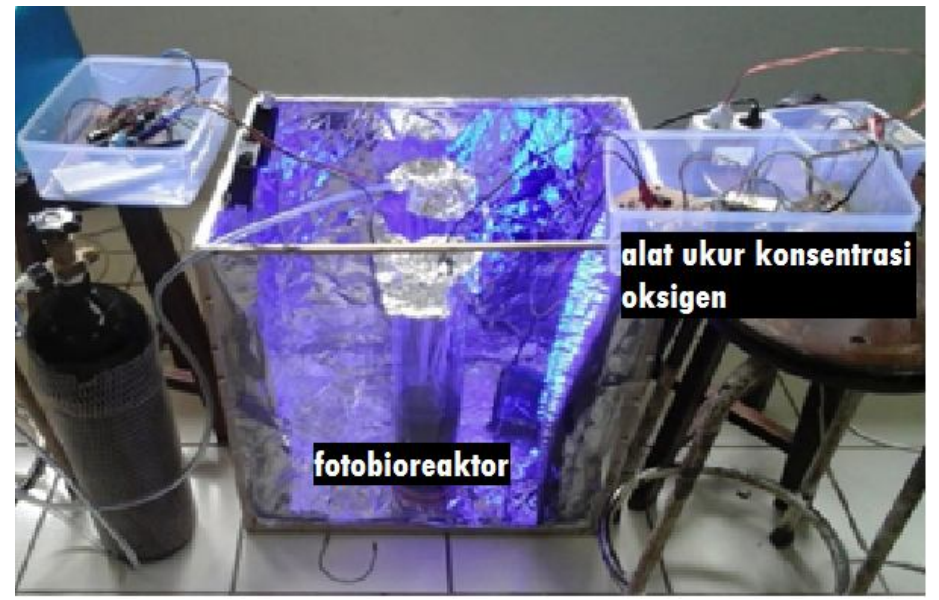

Gambar 8 Bentuk fisik alat keseluruhan

\subsection{Hasil Karakterisasi Sensor SK-25F}

Pengujian awal sensor SK-25F dilakukan dengan melihat perbandingan antara tegangan keluaran pada sensor dengan nilai konsentrasi oksigen pada alat ukur pembanding. Pengujian sensor menggunakan dua alat ukur yang berbeda, hal ini bertujuan untuk melihat respon sensor dan nilai tegangan keluaran sensor jika diujikan dengan dua alat ukur yang berbeda. Pengujian dilakukan dengan memberikan beberapa variasi konsentrasi oksigen yang berasal dari tabung 
gas oksigen serta dari udara bebas. Data tegangan keluaran dari sensor diambil untuk setiap variasi konsentrasi oksigen dengan menggunakan multimeter digital.Data karakterisasi tegangan keluaran sensor dengan menggunakan dua alat ukur konsentrasi oksigen (Biogas Analyzer 5000 dan Gas Alert Microclip) dengan beberapa variasi nilai konsentrasi oksigen dapat dilihat pada Gambar 9.

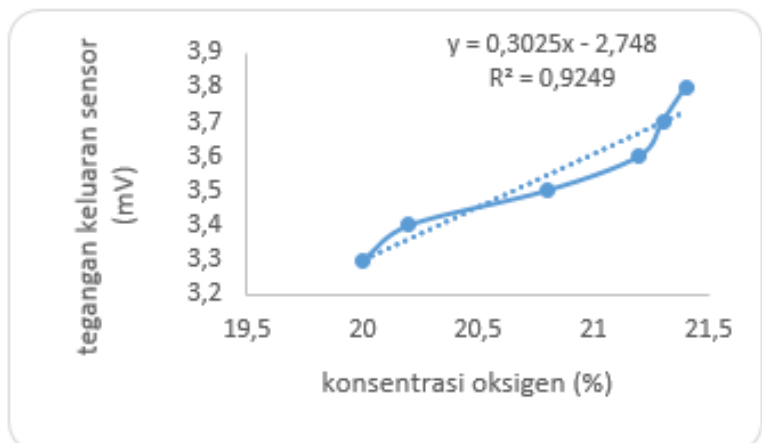

(a)

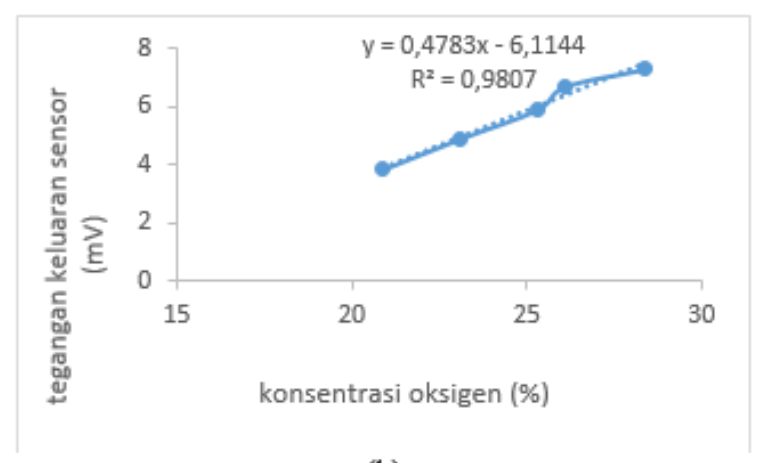

(b)

Gambar 9 Hubungan tegangan keluaran sensor dengan konsentrasi oksigen

Gambar 9 menunjukkan perbandingan antara tegangan keluaran sensor dengan konsetrasi oksigen yang terukur pada 2 alat ukur yang berbeda. Gambar (a) merupakan regresi linear antara tegangan keluaran sensor dengan Gas Alert Microclip dan (b) dengan Biogas 5000 analyzer. Hasil regresi linear pada gambar (a) yaitu $y=0,4783 x-6,114$. Variabel $x$ merupakan nilai konsentrasi oksigen dan variabel y merupakan tegangan keluaran dari sensor. Angka 6,114 menyatakan nilai tegangan awal sensor saat nilai konsentrasi oksigen pada alat ukur mendekati nol. Pada setiap perubahan konsentrasi oksigen sebesar $1 \%$ mengakibatkan perubahan tegangan sebesar $0,4783 \mathrm{mV}$. Hasil regresi linear pada gambar (b) yaitu $y=0,3025 x$ 2,748. Pada setiap kenaikan nilai konsentrasi oksigen sebesar $1 \%$ mengakibatkan perubahan tegangan keluaran sebesar $0,3025 \mathrm{mV}$. Nilai tegangan keluaran awal sensor pada saat nilai konsentrasi oksigen pada alat ukur mendekati nol adalah -2,748. Hasil derajat korelasi linear diperoleh sebesar $R^{2}=0,9807$ untuk Gas Alert Microclip dan $R^{2}=0,924$ untuk Biogas 5000 Analyzer. Kedua nilai ini sudah menunjukkan bahwa hubungan antara tegangan keluaran sensor dengan nilai konsentrasi oksigen pada alat ukur adalah linear. Fungsi transfer yang diperoleh dari hasil karakterisasi sensor dimasukkan ke list program mikrokontroler. Gas Alert Microclip merupakan alat ukur konsentrasi oksigen yang dipakai sebagai acuan, sehingga fungsi transfer yang dimasukkan adalah fungsi transfer dari karakterisasi sensor oksigen dengan alat tersebut.

\subsection{Hasil pengujian rangkaian penguat non-inverting}

Tegangan keluaran sensor oksigen yang masih dalam skala $\mathrm{mV}$ harus dikuatkan terlebih dahulu agar bisa dibaca oleh Arduino. Tegangan keluaran rangkaian penguat non-inverting untuk sensor oksigendapat dilihat pada Tabel 1. Tegangan keluaran sens233wr yang awalnya masih dalam skala $\mathrm{mV}$ telah dikuatkan sehingga menjadi skala V. Keluaran sensor dapat diproses oleh Arduino setelah dikuatkan dengan menggunakan penguat non-inverting. 
Tabel 1 Hasil Pengujian Rangkaian Penguat Non-Inverting

\begin{tabular}{cc}
\hline Konsentrasi oksigen & Tegangan Keluaran $(\mathbf{V})$ \\
\hline $20,90 \%$ & 1,5 \\
$23,10 \%$ & 1,7 \\
$25,30 \%$ & 2,1 \\
$26,70 \%$ & 2,2 \\
$28,40 \%$ & 2,4 \\
\hline
\end{tabular}

\subsection{Hasil Akhir Pengukuran dan Pengolahan Data}

Pengujian sistem pengukuran dilakukan untuk melihat keakuratan sistem yang telah dirancang. Hasil pengukuran nilai konsentrasi oksigen yang dihasilkan oleh fotobioreaktor dengan alat yang dirancang dibandingkan dengan alat ukur acuan (Gas Alert Microclip). Hasil pengukuran diuraikan pada Tabel 2.

Tabel 2 Hasil pengukuran konsentrasi oksigen yang dihasilkan fotobioreaktor

\begin{tabular}{|c|c|c|c|c|c|c|}
\hline \multirow{2}{*}{$\begin{array}{c}\text { Jam } \\
\text { ke- }\end{array}$} & \multicolumn{2}{|c|}{$\begin{array}{l}\text { Konsentrasi oksigen pada } \\
\text { alat yang dirancang }\end{array}$} & \multicolumn{2}{|c|}{$\begin{array}{c}\begin{array}{c}\text { Konsentrasi oksigen } \\
\text { pada alat ukur } \\
\text { acuan }\end{array} \\
\end{array}$} & \multicolumn{2}{|c|}{$\%$ error } \\
\hline & Tanpa $\mathrm{CO}_{2}$ & $\begin{array}{c}\text { Dengan } \\
\text { suplai } \mathrm{CO}_{2}\end{array}$ & $\begin{array}{c}\text { Tanpa } \\
\mathrm{CO}_{2}\end{array}$ & $\begin{array}{l}\text { Dengans } \\
\text { uplai } \\
\mathrm{CO}_{2}\end{array}$ & Tanpa $\mathrm{CO}_{2}$ & $\underset{\mathrm{CO}_{2}}{\text { Dengansuplai }}$ \\
\hline \multicolumn{7}{|c|}{ PENCAHAYAAN O LUX } \\
\hline 1 & $19,35 \%$ & $19,06 \%$ & $19,8 \%$ & $19,5 \%$ & $2,72 \%$ & $2,25 \%$ \\
\hline 4 & $19,24 \%$ & $19,61 \%$ & $19,7 \%$ & $19,4 \%$ & $2,33 \%$ & $0,82 \%$ \\
\hline 7 & $19,77 \%$ & $19,56 \%$ & $19,6 \%$ & $19,6 \%$ & $0,86 \%$ & $0,2 \%$ \\
\hline \multicolumn{7}{|c|}{ HALOGEN 5000 LUX } \\
\hline 1 & $20,2 \%$ & $20,2 \%$ & $20,9 \%$ & $20,5 \%$ & $3,25 \%$ & $1,46 \%$ \\
\hline 4 & $20,96 \%$ & $20,84 \%$ & $21,0 \%$ & $21 \%$ & $0,19 \%$ & $0,76 \%$ \\
\hline 7 & $20,3 \%$ & $20,43 \%$ & $20,8 \%$ & $20,9 \%$ & $2,40 \%$ & $2,25 \%$ \\
\hline \multicolumn{7}{|c|}{ LED 1065 LUX } \\
\hline 1 & $20,30 \%$ & $20,51 \%$ & $20,8 \%$ & $20,9 \%$ & $2,4 \%$ & $1,86 \%$ \\
\hline 4 & $20,33 \%$ & $20,38 \%$ & $20,4 \%$ & $20,6 \%$ & $0,34 \%$ & $1,07 \%$ \\
\hline 7 & $20,76 \%$ & $20,79 \%$ & $20,9 \%$ & $21,1 \%$ & $0,67 \%$ & $1,46 \%$ \\
\hline \multicolumn{7}{|c|}{ CAHAYA MATAHARI $( \pm 10.000$ lux $)$} \\
\hline 1 & $20,79 \%$ & $20,80 \%$ & $20,9 \%$ & $20,9 \%$ & $0,52 \%$ & $0,47 \%$ \\
\hline 4 & $20,91 \%$ & $20,89 \%$ & $21,1 \%$ & $21,3 \%$ & $0,9 \%$ & $1,92 \%$ \\
\hline 7 & $20,76 \%$ & $20,81 \%$ & $21,1 \%$ & $21,2 \%$ & $1,61 \%$ & $1,83 \%$ \\
\hline
\end{tabular}

Hasil pengukuran seperti pada Tabel 2 menunjukkan bahwa konsentrasi oksigen yang dihasilkan oleh fotobioreaktor dengan menggunakan sensor oksigen SK-25F dengan alat acuan hampir sama yang ditandai dengan nilai persen error yang kecil. Perbedaan nilai pengukuran yang diperoleh antara alat yang dirancang dengan alat ukur konsentrasi oksigen Gas Alert Microclipdisebabkan oleh adanya noiseyang muncul pada rangkaian penguat non-inverting, sehingga menyebabkan nilai tegangan keluaran rangkaian menjadi tidak stabil dan nilai konsentrasi oksigen yang terukur oleh alat yang dirancang sedikit berbeda dari nilai konsentrasi oksigen yang terukur pada alat ukur konsentrasi oksigen.

Konsentrasi oksigen maksimum dihasilkan oleh fotobioreaktor yang pada intensitas cahaya paling tinggi (5000 lux) pada jam ke-4 untuk cahaya buatan. Secara keseluruhan konsentrasi oksigen paling maksimum dihasilkan oleh fotobioreaktor dengan suplai karbon dioksida pada sumber cahaya matahari $( \pm 10.000$ lux $)$ pada jam ke-4. Hal ini disebabkan oleh fotosintesis paling optimum terjadi pada intensitas cahaya yang lebih tinggi dan dengan adanya penambahan karbon dioksida konsentrasi oksigen yang dihasilkan pada proses fotosintesis pun lebih tinggi.

Pada pencahayaan 0 lux konsentrasi oksigen yang diihasilkan oleh fotobioreaktor yang disuplai karbon dioksidajustrulebih rendah. Hal ini disebabkan pada saat gelap tidak ada fotosintesis yang terjadi sedangkan karbon dioksida terus disuplai ke fotobioreaktor, sehingga konsentrasi oksigen yang dihasilkanpun semakin berkurang. 


\section{KESIMPULAN}

Berdasarkan hasil yang diperoleh dan analisis yang telah dilakukan maka dapat disimpulkan bahwa alat ini dapat mengukur konsentrasi oksigen yang dihasilkan oleh fotobioreaktor mikroalga Chlorella vulgarisdengan rata-ratapersen erroralat keseluruhan sebesar $1,383 \%$. Karakterisasi sensor SK-25F terhadap konsentrasi oksigen menghasilkan nilai sensitifitas sensor sebesar 0,478 dan $R^{2}=0,980$ untuk alat ukur Gas Alert Microclip dan $R^{2}=$ 0,924 untuk alat ukur Biogas 5000 Analyzer.Nilai konsentrasi oksigen maksimum dihasilkan oleh fotobioreaktor yang disuplai karbon dioksidadengan sumber cahaya lampu halogen 5000 lux danmatahari. Nilai konsentrasi oksigen minimum dihasilkan pada fotobioreaktor pada pencahayaan 0 lux dengan disuplai karbon dioksida. Sehingga berdasarkan hasil pengukuran untuk menghasilkan konsentrasi oksigen yang maksimum, suatu fotobioreaktor harus disuplai dengan karbon dioksida dan disinari dengan sumber cahaya berintensitas di atas 5000 lux.

\section{DAFTAR PUSTAKA}

Bishop, J., dan Davis R., Autonomous Observing Strategies for The Ocean Carbon Cycle, Lawrence Berkeley National Laboratory, California, 2000.

Chrismadha, T., Sutapa, I., Hidayat, Rosidah, dan Mardiyati, Y., Pengaruh Cahaya Intermitan terhadap Fotosintesis Kultur Alga Chlorella vulgaris, Jurnal Oseonologi dan Lirnnologi, Jurusan Fisika Institut Teknologi Sepuluh Nopember (ITS), 2000.

Daniyati, R., Yudoyono, G., Rubiyanto, A., Desain Closed Photobioreaktor Chlorella vulgaris Sebagai Mitigasi CO2, JurnalSainsdanSeni ITS, Jurusan Fisika Institut Teknologi Sepuluh Nopember (ITS), 2012.

Ersan, L., O., Pembuatan Pola Tingkat Pembakaran Melalui Deteksi Emisi Gas Buang Pada Motor Bensin Karburator Sistem 4-Tak Menggunakan Sensor Gas Dengan Metode Fast Fourier Transform (FFT), skripsi, Jurusan Sistem Komputer FTI Unand, 2013.

Figaro, SK-25F technical info 1112, Figaro Engineering Inc., Osaka, 2012.

Santoso, D., A., Rahmania, Darmawan, A., Joko P, Mikroalga untuk Penerapan Emisi $\mathrm{CO}_{2}$ dan Pengolahan Limbah Cair di Lokasi Industri. Jurnal dan Teknologi Kelautan Tropis, Pusat Teknologi Lingkungan- BPPT, Jakarta, 2011. 